\title{
Business intelligence, além dos mitos
}

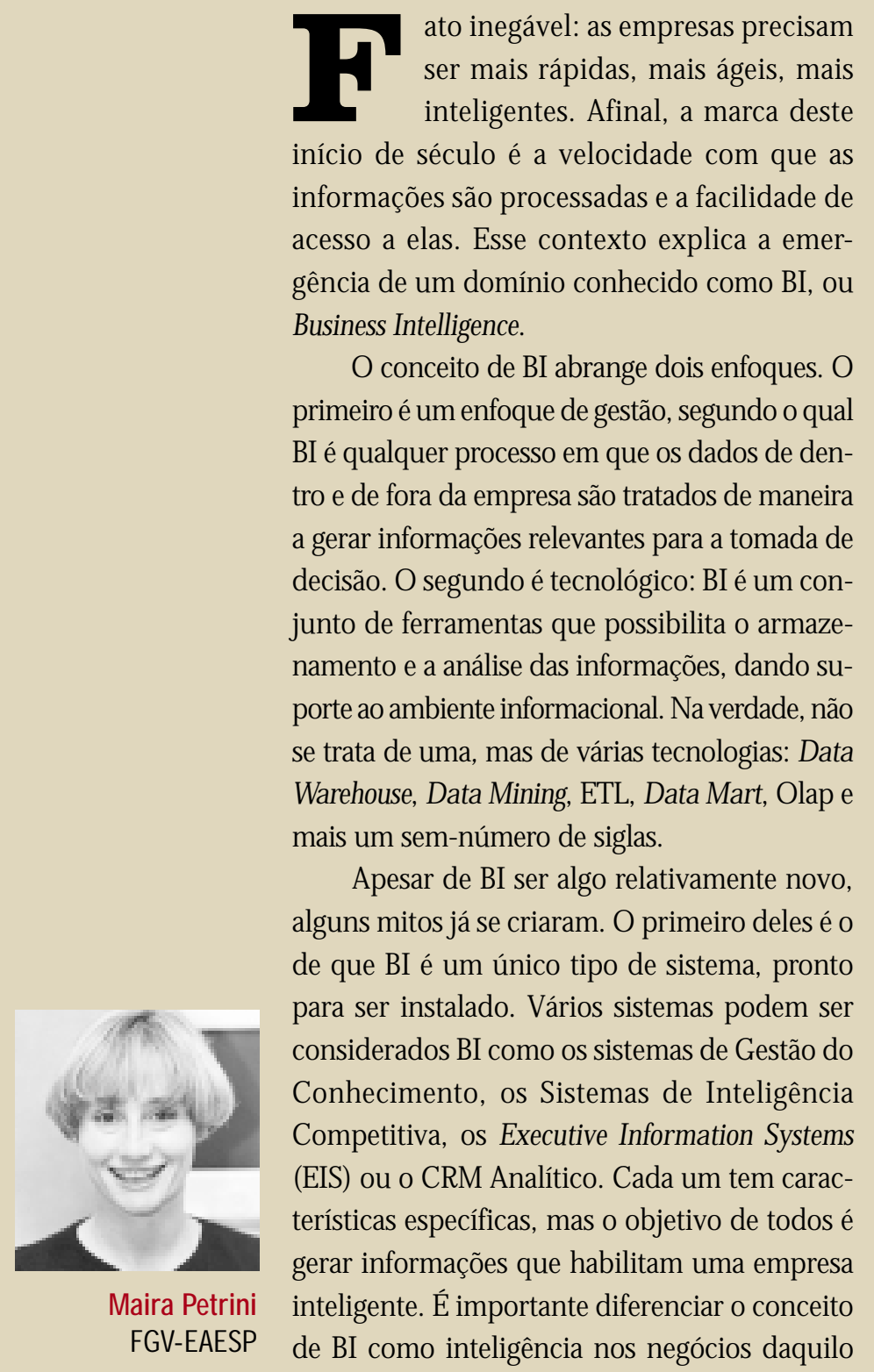

que as consultorias em Tecnologia de Informação vendem como Bl: normal mente, as soluções oferecidas são um conjunto de softwares que implementam os EIS, ou seja, o monitoramento de indicadores de desempenho em diferentes dimensões de negócio. BI também não é um "pacote" pronto para ser instalado: 0 desenvolvimento de $\mathrm{BI}$ requer um processo coletivo e contextualizado de extração, análise e distribuição dos mais variados tipos de informação.

0 segundo mito a ser derrubado é o de que as velhas planilhas são sistemas de apoio à decisão. Elas de fato podem ajudar, se aplicadas adequadamente. Mas há um momento em que se perde o controle. É o que acontece em reuniões nas quais o gerente financeiro tem um número e o gerente comercial, outro - cada um com sua planilha, sua "ilha" de informações.

$\mathrm{BI}$, por sua vez, cria um "ambiente informacional único", no qual os dados operacionais associados aos dados externos podem ser manipulados de forma analítica sob as mais diversas dimensões de negócio, garantindo que todas as áreas da empresa acessem as mesmas informações.

Talvez seja prudente encerrar frisando o que não é BI: não é um pacote pronto e único, nem uma planilha cheia denúmeros. As empresas que já enfrentaram o desafio sabem que o processo é complexo, mas colhem os frutos por terem despachado as planilhas para 0 arquivo morto da história corporativa. 